Mott, and published uuder the auspices of the London County Council. Mr. Horsley concluded his lecture by stating that from a scientific standpoint the contention so often put before them that small doses of alcohol, such as people took at meals, had practically no deleterious effect could not be maintained. He had only touched on a very small part of the subject, but if they considered the observations of Parkes on physical work, of Ridge on small doses of alcohol on vegetable protoplasm, and of Abbott and others on the influence of alcohol in rendering animals more prone to microbic invasion, they could only come to the one conclusion-that from a scientific standpoint total abstinence must be their course if they were to follow the plain teaching of truth and common sense.

The Dran of Canterbury (the Very Rev. F. W. Farrar) moved a vote of thanks to Mr. Horsley, which was seconded by Dr. W. J. Coclins, who said he was glad to see that members of Boards of Guardians were present, and he trusted they would apply practically the information which had been imparted scientifically to them.

Sir WILFRID Lawson moved a vote of thanks to the Chairman in a humorous speech, and referred to public houses as "the styes which law has licensed."

Mr. T. P. WhitTaker, M.P., seconded the resolution, which was responded to by the CHaIRMaN, who said that as a moderate drinker he agreed that some of the pictures which were thrown on the sheet were of a disagreeable character, and he could only say that they would receive from him the very careful consideration that they deserved. He confessed that when Mr. Horsley pointed out in the brain the particular spot for the operation known as winking, he could not but think of how frequently leading politicians on both sides of the House had winked their eye whenever the temperance question was mentioned, and he had not thought before that night that they had been exercising their brain power when so engaged, but he now knew that a merciful Providence had fashioned for them an apparatus to enable them to go through that process. But the brain also compelled their movements and directed their legs, and what he wanted to see was the legs of members of Parliament directed into the right lobby, and for that purpose the electorate played the part of the cerebellum.

\section{THE MIDWIVES BILL.}

Amendments Nhoessary.

Sir,-May I be allowed, through the columns of the BritisH Medical Journal, to draw attention to the important resolution on the midwives question which I had the honour to propose, and which was unanimously adopted, at the last meeting of the Council of the British Medical Association?

This resolution clearly defines the position of the Council and unites all of us - whether opposed to legislation or compelled, however unwillingly, to recognise that legislation is inevitable-in an emphatic and unanimous condemnation of the Midwives Bill at present before Parliament, inasmuch as, in the expressed opinion of the Council, the present Bill, if it became law, would be a direct danger to the public safety.

Long ago the Lancashire and Cheshire Branch, after mature deliberation, and foreseeing the present state of matters, dfcided to be prepared with a clearly-defined scheme which might at once be launched in opposition to any Bill of the Midwives Committee that threatened to become law. In this scheme the following points were laid down as absolutely essential in order to prevent the so-called "registration of midwives" from being a grave disaster for the well-being of the State :

r. Definition of midwife : This must $(a)$ impose attendance on the mother and child after, as well as during, labour; and $(b)$ restrict her practice to natural labour.

2. There must be a statutory penalty for practice as well as for the assumption of title.

3. There must be a statutory penalty for malpraxis or misconduct. of medical practitioners.

5. Compulsion of midwife to send for doctor in case of anything abnormal or illness.

6. Direct medical supervision of midwives necessary.

Needless tn say not one of these essential conditions is safeguarded in the present Bill except Point 2, and as to this point the promoters of the Bill have actually promised that any amendment, which shall make the penalty apply only to those who assume a title, shall be "benevolently considered."

The resolution I proposed at the last Council meeting directed the General Secretary to write to all Secretaries of Branches, urging them to use all local means in their power " to obtain amendments to the Bill."

May I suggest that every Branch should have a special meeting at the earliest possihle date, adopt the following amendments (which would secure the above principles), and, using all local influences, approach their local members of Parliament (directly and through the local political associations, especially the women's committees), urging them to vote for the adoption of these amendments, and in case of failure to vote solidly against the third reading?

The following are the necessary amendments :

I.

Page 2, Clause 2, Sect. v, line 2

Mr. Lloyd-George has given notice that he will move to insert at the end of line 2 the following words: "and if any woman certificated under this Act shall do or purport to do anything which by this subsection it is declared that her certificate does not confer upon ber a right or title to do she shall be liable on summary conviction to a fine not exceeding five pounds.'

This will secure Point 3 .

Page 2, Clause 4, line 14

Dr. Farquharson has undertaken the following

After "practitioners," leave ont to end of subsection ( 1 ) and inser "to be appointed by the General Medical Council as follows: One practising in the London and South-Eastern Registration Divisions, one pracising in the South-Western, West Midland, or Welsh Registration Divisions; one practising in the Eastern, North Midland, or South Midland Registration Divisions; and one practising in the Yorkshire or Northern Registration Divisions, as from time to time defined by the Registrar General."

This will secure Point 4

Page Clause Subsection

After the word" "misconduct," insert " and so that for the purposes of this Act the omission to summon a registered medical practitioner in a case of abnormal labour or danger to or illness of the mother or child,

This will secure Point 5 .

Omit the words from the beginning of the clause down to the word "borough" (inclusive) in line 24, and substitute, "Every county council of any administrative county and county borough throughout England and Wales shall, on the passing of this Act appoint a committee of not fewe than three registered medical practitioners, two of whom shall not be than three registered medical practitioners, two of whom shall not be over midwives within the area of the said county."

This would partially secure Point 6.

Page 6, Clause r8, line 30.

V.

Sir George Pilkington has undertaken the following

Leave out all the words from "childbirth" to "employed," both inclu sive, and insert "in natural labour but not in cases which presen tabnor malit,, danger, or disease, on the part of the mother or of the newbors child."

In order to secure Point I it would be necessary that this amendment should read "in natural labour and during the lying-in period, etc."

In regard to Point 2, Colonel Milward has given notice of the following: : birth," in line 18.

This amendment should be strenuously resisted.

If these points could be secured the Bill would be rendered much less harmful, otherwise we shall, I fear, live to regret the absence of " medical union." -I am, etc., Manchester, April zoth.

T. Arthur Helme.

\section{THE PLAGUE.}

\section{Prefalence of the Diskase.}

INDIA.

IN the Bombay Presidency the total number of plague deaths during the week ending April ist numbered 1,462, of which 659 occurred in the city of dimini ise sem to diminish. Of April $5 \mathrm{~h}, 6 \mathrm{th}, 7 \mathrm{th}, 8 \mathrm{th}, 9 \mathrm{~h}$, roth, and rith the number of new cases of plague were respectively 139, 157, 143. 131, rrg. 119, and 125; deaths from plague for the week ending April roth 730 .

In be spreading to an alarming extent. The return for the six days andin April soth shows 433 new cases and 315 deaths from the disease ending April roth shows 433 new cases and 315 deaths from the disease. Bince January 1st, 1900 , to April 5 th 1.052 cases of plague have occurred in
Karachi and 756 deaths. Seeing that nearly half the deaths have occurred 